\title{
Brief Considerations About the Brazilian Secular State
}

\author{
Natammy Luana de Aguiar Bonissoni \\ Postgraduate Law Program, University of Vale do Itajaí, Itajaí, Brazil
}

\section{Email address:}

natammy@hotmail.com

\section{To cite this article:}

Natammy Luana de Aguiar Bonissoni. Brief Considerations About the Brazilian Secular State. International Journal of Law and Society. Vol. 2, No. 3, 2019, pp. 54-57. doi: 10.11648/j.ijls.20190203.15

Received: August 14, 2019; Accepted: September 20, 2019; Published: September 30, 2019

\begin{abstract}
Law and religion do not mix. This is one of the fallacious maxims of recent years and that unfortunately brings several misunderstandings when it comes to the relationship between the state and the religious phenomena. It is not hard to see that countless perceptions on the subject, when presented in the media, academic, social and legal fields, do not take into account the constitutional foundations, the cultural values and, especially, the spiritual character of the human being as the structuring of human life. Nowadays, Brazil has been facing political and legal problems in view of the lack of understanding of the principle of Secularity applied in the Brazilian context. By electing an openly religious President, defender of the customs and practices of his religious belief, the comprehension of the subject is necessary to set aside misconceptions, in order to address the issue with the seriousness and scientificity that it deserves. In this sense, the purpose of this article is to clarify what it means to be a secular Brazilian State, aiming to demonstrate, as a result, that the secular model adopted in Brazil does not mean the absence of religiousness in the public sphere, but the guarantee and protection of all its expressions.
\end{abstract}

Keywords: Brazil, Religion, Religious Freedom, Secular State, Secularity

\section{Introduction}

Eric Voegelin [1] when analyzed the model of order that organized the great societies, initially the Near Eastern civilizations, found that they all understood themselves as mirrors of a cosmic order. Unlike today, the empires of the past did not transcend their own realm, as they perceived themselves as a reflection of the cosmos. Thus, as divinity ordained the cosmos, the King similarly ordained society.

Jewish tradition broke with this kind of civilization. In Israel, for the first time in history, man comes into contact with a being, God (a supra-cosmic entity) which until then was unthinkable for cosmological civilization. Voegelin then realizes that it is only now, after the human being comes into contact with a supra-cosmic being, that the story begins. The understanding that there is a being, above the social order itself, that instituted, ordained and established norms for all spheres, led to the proposition of objective and absolute norms to be respected in all time and space.

Thus, by analyzing the development of the ancient civilizations, the formation of the Hebrew theocracy, the divine character granted to the Roman emperors and the construction of the concept of civil religion in the modern state, it can be perceived the influence of religion on the most diverse areas of the social, including politics. However, the rupture caused by the French Revolution, between the State and religion, represented a new fact in the history of civilizations.

Since then, it is possible to realize the birth of several models of secularism, and each one of them takes into account the cultural, religious, political and legal context of each nation. Therefore, every model of relationship between the State and the religious phenomenon needs to be analyzed considering a historical background, both legal and political, but, in the end, considering that there is always a religious presupposition.

The misconceptions caused after the French Revolution, about the definition of secularism and the characteristics of the Secular State, presented social, media and even artistic manifestations that misunderstands the real meaning of the institutes, especially in Brazil. Therefore, due to the complexities of political factors that occur as a result of cultural issues based on religious precepts, it is important to verify in the current Brazilian legislation, the influence of religion on social dynamics, and then identify its natural repercussion in the model of the Secular State.

In this sense, the present study aims to briefly identify the 
model of the Secular State adopted by Brazil in an attempt to undo certain doubts, so that an adequate interpretation of constitutional devices demystifies fallacies and dispel certain misunderstandings.

\section{Religion and Life in Society}

Julie Riens, founder of fundamental religious anthropology as a new field of knowledge, defends the understanding that the human being, since its origin, is a religious man. [2] From the earliest times, through the influence of Greek thought and the contributions of Roman law, it was found that from the rationalism and the intense process of secularization suffered by the West, the metaphysical and religious universes were set aside and scientism emerged as a sure conductor to the truth.

The realization that man has the right to exercise and manifest his religiosity has spanned centuries, developing organically and influencing the development of other fundamental freedoms. Thomas Jefferson understood the right of man to manifest his religiosity as the most sacred and inalienable right of all human rights. [3]

After nearly two hundred years, the protection of freedom of religion in the Universal Declaration of Human Rights has revealed a high degree of global - albeit unanimous consensus on its importance "for the preservation of the dignity of the human person and for coexistence between the peoples" [4]. However, despite all the historical development and recognition in political and international documents on the subject, Malcom Evans [5] considered freedom of religion or belief as a "forgotten process," a human right that, compared to others, has not been well-regarded successfully.

It is important to highlight that international instruments of protection that safeguard the right to freedom of religion do not define the meaning of the term religion, which demonstrates the challenges in verifying what exactly can be framed as religion or belief. For the European Council, for example, the failure to provide a clear definition of the term is purposeful, and that shortcoming is right in the need for the conceptualization of the term to be comprehensive enough to embrace the full range of religions in Europe while being specific enough to apply to individual cases. [6]

It is evident, therefore, that religious freedom can imply having a religion, not having a religion, changing religion, sharing one's religion, practicing the inherent rites of religion, and instructing children according to the precepts of their religion. [7]

According to the Commentary on the American Convention on Human Rights [8], religious liberty "is free to profess in the name of a religion, understood as the relationship of the man to the divine (not necessarily to a personal person, but to the divine) which is a relation to the transcendence) of which some ethical beliefs, opinions, beliefs, and religious observances come from the outside which are positively externalized through the free individual or collective manifestation, public or private, through various particular specifications. The protected good of that freedom is not precisely religion but human freedom exercised in the religious sense, which deserves protection and promotion for its full enjoyment and exercise.

Thus, supported by the Universal Declaration of Human Rights and the American Convention on Human Rights, as well as by several international treaties, it is clear that the right to freedom of religion in Brazil is not disseminated and protected in the same way as in other states and international organizations, which may justify many misunderstandings and even a certain confusion as to its implications in relation to the principle of secularity and the secular state.

\section{What the Principle of Secularity Is Not}

French social scientists such as Pierre Bréchon, Gustave Peiser and Jean-Paul Willaime have drawn a distinction between secularity of aggressive combat (laïcité du combat), whose purpose is to combat the influence of religion and priests, and secular cohabitation, or secularity of tolerance and flexibility (laïcité ouverte), which allows greater space for the religious in the public sphere. César Ranquetat Junior reflects Bréchon's position on aggressive secularism, which argues that the model seeks to "[...] exterminate religion, make it disappear from social life and eradicate it from individual consciences." [9]

For the Spanish sociologist Millán Arroyo Menéndez [10], secularism, as the French model of secularism is also understood, can be characterized as "anti-religious belligerent, the least anti-clerical, and eventually developing a vision of the alternative world, which came into direct competition with the religious view of the world. Its greatest historical expression was the communist ideology, which impacted on all the territories from which communism was impelled as a political form."

A good example that demonstrates the performance of the French model is the data shared by the Pew Research Center, which identified France as the only European Union member state to hold more than 200 cases of government actions against religious groups - mostly cases of individuals being punished for violating the ban on facial coverage in public spaces and government buildings in France.

It is interesting to note that this aggressive secularism (laïcité du combat) was experienced by Brazilians during the 1937 Constitution, where it was possible to perceive serious restrictions on religious freedom, including the loss of political rights in case of lack of conscience. [11]

Although the French model is aggressive and even considered by many to violate the universal right to exercise the right to freedom of religion, it can be seen that there is a clear difference between the secularism operated in France, for example, and the active secularism in Brazil, which is clearly not secularist, that is, anti-religious and contrary to the religious faith.

\section{The Brazilian Secular State}

During the imperial period, the Brazilian State adopted in 
the 1824 Constitution the model of Confessional State, at which time it declared the Roman Apostolic Catholic religion as its official religion. At that time, other religions were allowed to exist, as long as they acted domestically and without the exterior form of a temple, which, in practice, denied the majority of religions the clandestinity. [12]

In 1891 Brazil became secular with the implementation of the republican mode of government. Ruy Barbosa, charged with drafting the new constitutional text, has made the Brazilian state secular by promoting equality among all religions, including decree $119-\mathrm{A} / 1890$ [13], which is in force until today and that it prohibits state intervention or embarrassment over any church or religion. [14]

Thiago Rafael Vieira and Jean Marques Regina [15] affirm that Decree 119-A/1890 clarifies any doubts about the model of secularism adopted by the Brazilian Republic: a neutral secularity, guaranteeing the spiritual order, expressed through the religious phenomenon manifested by through each person's faith and the value set they believe in, often wrapped up in the form of a religious organization.

Religious freedom, currently guaranteed by the Federal Constitution, is only possible due to the neutrality presented in art. 19, I, regulated by Decree 119-A/1890. In this context, it is possible to clarify the model of secularism in Brazil from four constitutional prohibitions by the state: a) the establishment of religious cults or churches; b) the subsidy of certain religious cults or churches; c) embarrassment to the operation of religious cults or churches; and d) maintaining relations of dependence or alliance with religious cults, churches or their representatives. [16]

By exclusion, it can be seen that the Brazilian state is not theocratic in view of the prohibition of the establishment of religious cults or churches; neither is it confessional, judging from the impossibility of subsidizing or maintaining religious services or churches, or maintaining a relationship of dependence or alliance with them. Moreover, the Brazilian State is not an atheist or a combatant secularist since it is forbidden to hinder the functioning of religious cults or churches. [17]

In this way, the Constitution protects religious freedom with the aim of making it easier for people to enjoy their faiths. [18] as well as exercise them without any embarrassment or impediment, besides having them as the basis of their actions, decisions and conducts. It is important to point out that, although admittedly considered a matter of intimate forum, the exercise of religiosity is beyond the figure of the individual, not being considered an accessory part of human life, but the elementary center of their choices and orientation, whether they are religious or from the denial of religiosity.

Contemporary documents protecting individual human rights ensure such insight and contribute to national recognition of the rights to freedom of conscience and religion. Both the Universal Declaration of Human Rights and the International Covenant on Civil and Political Rights and the European Convention on Human Rights consider as absolute and unconditional the right to have a belief or to change it at one's own discretion, preventing state interference in any option.

It is important to emphasize that although the Law cannot be an instrument to regulate or even control the individual's relationship with God, the exercise of religiosity can be accompanied by the State for the common good of the community. Although the purpose of this brief essay is not to go into detail about the many consequences of exercising freedom of religion, it is important to note that certain limitations may be justified in the pursuit of the common good of the State, both spiritual and temporal, as well as in the principle of the dignity of the human person. The succinct argument can find support by bringing to the debate the discussion of female genital mutilation and child marriage, defended as legitimate on the basis of religious assumptions and that subjugate countless women of different beliefs, local cultures to acts contrary to their will.

Finally, the fact that religious organizations are not subservient to the state, such as tax immunity as a consequence of secularism and not as a privilege granted by it; Constitutional protections concerning the freedoms of belief, worship and conscientious objection demonstrate respect, guarantee and protection of the spiritual order and, consequently, the religious phenomenon. [19]

From this angle, it is possible to verify that the secularity model adopted by the Brazilian state is collaborative with the state, completely distancing itself from the French secularism. That is, the model of the secular state in Brazil grants the right and the guarantee of the exercise of religiosity in all its spheres and through all expressions.

\section{Conclusions}

The influence of religiosity on human and social life, recognized by historians of antiquity and enshrined in international and constitutional documents, allows today different religions and creeds, whether of Eastern, Western, African, etc., to live together in harmony in one another Constitutional State through the principle of secularism.

There are innumerable understandings about this principle and even some controversies about the relationship between the State and the religious phenomenon, which make misunderstandings about the subject spreading the idea that the Brazilian State can adopt a model similar to the French, opponent and combatant of religiosity.

In this sense, it was considered relevant to analyze the constitutional understanding of the relationship model of the Brazilian state with the religious phenomenon. Thus, it was possible to identify that the way in which Brazil relates to religion is through the model of collaborative secularism, which allows citizens, both individually and collectively, the possibility of expressing themselves and manifest their religiosity in the public sphere under a constitutional protection, whether through the presence of symbols, the occurrence of religious meetings in public spaces and even through the sacrifice of animals for religious purposes.

It is important to stress, therefore, that religious freedom 
should not be understood as a favor of the state, a benevolent concession that allows citizens of a given territory to exercise their faith. The principal foundation of the right to religious freedom and its exercise in society does not come from the figure of the state, but is rooted in the transcendent character of the welfare state itself. That is, the religion. Therefore, its exercise must be respected and safeguarded by it, in order to protect one of the most intimate, sensitive and innate rights of the human person: the right to exercise and practice his religion.

\section{References}

[1] Voegelin, Eric. Order and History: Israel and Revelation. Ed. 3. São Paulo: Edições Loyola, 2014.

[2] RIES, Julien. The man has been religious since the time of the australopitech Lucy. Unisinos Humanitas Institute. Interview given to Andrea Tornielli, published on the Vatican Insider website and translated by Moses Sbardelotto. Available at: http://www.ihu.unisinos.br/noticias/505568-o-man-ereligioso-desde-o-tempo-do-australopiteco-lucy-entrevistacom-julien-ries. Access on Mar, 2019.

[3] JEFFERSON, Thomas. Thomas Jefferson on Politics \& Government. Available at: https://famguardian.org/subjects/politics/thomasjefferson/jeff1 650.htm. Access on Sep. 2019.

[4] DOS SANTOS JUNIOR, Aloisio Cristovam. Religious Freedom and Employment Contract. Niterói: Impetus, 2013. P. 90 .

[5] EVANS, Malcolm. Advancing Freedom of Religion or Belief: Agendas for Change. Forum 18 News Service. Available at: http://www.refworld.org/docid/4df7312a2.html Accessed on Sep 2019.

[6] ECRH. European Court of Human Rights. Council of Europe. Guide to article 9 -Freedom of thought, conscience and religion. Available at: https://www.echr.coe.int/Documents/Guide_Art_9_ENG.pdf.

[7] PASCHOAL, Janaína Conceição. Religion and Criminal law: interfaces on seemingly distant themes. Sao Paulo: Liber Ars, 2017. p. 69.

[8] STEINER, Christian; URIBE, Patricia. American Convention on Human Rights - Comment. Bolívia: Plural Editores, 2014. Available at: https://www.kas.de/c/document library/get file?uuid $=03728 \mathrm{c}$ 83-4b96-d946-e66a-9b52b6adcbb7\&group $\overline{I d}=252038$. Accessed on Sep, 2019.

[9] RANQUETAT JR; Caesar. Secularity, laicism and secularization: defining and clarifying concepts. Revista Sociais e Humanas. V. 21. N 1 2008. Available at: https://periodicos.ufsm.br/sociaisehumanas/article/view/773/5 32. Accessed on Sep 2019.

[10] ARROYO, Millan. The power of religion and secularization in Europe. Available at: http://eprints.ucm.es/5864/1/224-32ANALISIS.pdf. Accessed on Sep 2019.

[11] VIEIRA, Thiago Rafael; REGINA, Jean Marques. The Brazilian Collaborative Secular State. Available at: https://www.ibdr.org.br/publicacoes/2017/3/1/morbi-vitaenisl-4 Access on Sep 19, 2019.

[12] VIEIRA, Thiago Rafael. O Estado Laico Brasileiro. VR Advogados. Available at: http://vradvogados.adv.br/home/oestado-laico-brasileiro/. Access on Jul 07, 2017.

[13] BRASIL. Decree 119-A/1890. Available at: http://www.planalto.gov.br/ccivil_03/decreto/1851-1899/d119a.htm. Access on Mar 31, 2019.

[14] VIEIRA, Thiago Rafael; REGINA, Jean Marques. Direito Religioso: questões práticas e teóricas. Ed. 2. Porto Alegre: Concórdia, 2019. P. 130.

[15] VIEIRA, Thiago Rafael; REGINA, Jean Marques. Direito Religioso: questões práticas e teóricas. Ed. 2. Porto Alegre: Concórdia, 2019. P. 131.

[16] VIEIRA, Thiago Rafael; REGINA, Jean Marques. Direito Religioso: questões práticas e teóricas. Ed. 2. Porto Alegre: Concórdia, 2019. P. 138.

[17] VIEIRA, Thiago Rafael; REGINA, Jean Marques. Direito Religioso: questões práticas e teóricas. Ed. 2. Porto Alegre: Concórdia, 2019. P. 139.

[18] MENDES, Gilmar Ferreira; BRANCO, Paulo Gustavo Gonet. Constitutional law course. Ed. 9. São Paulo: Saraiva, 2014. p. 319.

[19] VIEIRA, Thiago Rafael; REGINA, Jean Marques. Direito Religioso: questões práticas e teóricas. Ed. 2. Porto Alegre: Concórdia, 2019. P. 144. 